\title{
ANALISA BIAYA DAN WAKTU DENGAN MENGGUNAKAN METODE TIME COST TRADE OFF PADA PROYEK PEMBANGUNAN HOTELASTON PARAMOUNT MALANG
}

\author{
Iktiva Sani', Zamzami Septiropa² \\ ${ }^{1,2}$ Jurusan Teknik Sipil Fakultas Teknik - Universitas Muhammadiyah Malang \\ Alamat korespondensi : Jalan Raya Tlogomas 246 Malang 65144
}

\begin{abstract}
Implementation of Development Projects Aston Paramount delayed completion time caused by the discharge of water continuously from the underground, thus flooding the area GWT (Ground Water Tank), STP (Sewage Treatment Plan) and the destruction of Tower Crane. It can be based on time schedulle project in November 2012 or at the time the project reaches 17 weeks, the progress of the plan should reach $28.648 \%$, but the reality on the ground has reached $24.194 \%$, so it can be known deviation $-4.454 \%$. The method applied in this researchTime Cost Trade Off (TCTO) to speed up implementation of the project in order to achieve the optimum time in the rest of the work project. TCTO a time and Biya exchanges with a view to speeding up the duration. Acceleration time is done by holding the shift work. Of the project schedule has been delayed, the rest of the project is completed within 180 days for a total cost of Rp. 32,679,810,571.24. However if the project accelerated by using TCTO to return to the original plan schedule is 162 days obtained a fee of Rp. 33,462,446,260, the difference between the cost of Rp. 782,635,689.88.
\end{abstract}

Keywords: Time and Cost

\begin{abstract}
Abstrak
Pelaksanaan Pembangunan Proyek Aston Paramount waktu tertunda penyelesaian disebabkan oleh debit air terus menerus dari bawah tanah, sehingga banjir daerah GWT (Ground Water Tank), STP (Sewage Treatment Plan) dan penghancuran Tower Crane. Hal ini dapat didasarkan pada proyek schedulle waktu pada bulan November 2012 atau pada saat proyek mencapai 17 minggu, kemajuan rencana harus mencapai $28,648 \%$, namun kenyataan di lapangan sudah mencapai $24,194 \%$, sehingga dapat diketahui penyimpangan $-4,454 \%$. Metode yang digunakan dalam penelitian ini Time Cost Trade Off (TCTO) untuk mempercepat pelaksanaan proyek dalam rangka mencapai waktu optimal dalam sisa proyek kerja. TCTO waktu dan Biya pertukaran dengan maksud untuk mempercepat durasi. Percepatan waktu dilakukan dengan memegang shift kerja. Dari jadwal proyek mengalami keterlambatan, sisa proyek selesai dalam waktu 180 hari dengan biaya total Rp. 32,679,810,571.24. Namun jika proyek dipercepat dengan menggunakan TCTO untuk kembali ke jadwal rencana semula adalah 162 hari diperoleh biaya sebesar Rp. 33462446260, perbedaan antara biaya Rp. 782,635,689.88.
\end{abstract}

Kata kunci: Waktu dan Biaya

\section{PENDAHULUAN}

Proyek Pembangunan Hotel Aston Paramount merupakan pembangunan hotel yang ada di Malang. Perkembangan bisnis di dunia perhotelan di kota Malang semakin pesat, ditandai dengan banyaknya pembangunan hotel yang menawarkan berbagai macam fasilitas. Hotel ini nantinya akan digunakan sebagai pusat mobilisasi bisnis dan tempat beristirahat dengan layanan kualitas dan privasi yang baik. Proyek Pembangunan Hotel Aston Paramount direncanakan untuk menfasilitasi bagi pengguna pelayanan hotel yang dapat memperlancar pertumbuhan ekonomi suatu daerah yang ada dikawasan Malang.

Penyelesaian proyek pembangunan hotel ini memerlukan ketelitian dalam proses pengerjaanya serta ketepatan waktu sesuai dengan jadwal yang telah direncanakan, tanpa adanya keterlambatan. Pada kenyataannya pembangunan proyek hotel ini mengalami progres keterlambatan di dalam waktu pelaksanaan pekerjaanya dari jadwal rencana yang sudah dibuat. Pembangunan Hotel Aston Paramount dilaksanakan selama 42 minggu. Berdasarkan 
laporan pekerjaan minggu ke 17 pada tanggal 5 November 2012 sampai 11 Oktober 2012, terlihat bahwa proyek mengalami keterlambatan. Pada minggu ke 17 proyek seharusnya sudah diselesaikan $25,673 \%$, namun pada kenyataannya proyek baru diselesaikan 24,194\%, hal ini berarti bahwa proyek mengalami keterlambatan -1,478\%. Sedangkan sisa waktu pelaksanaan adalah 25 minggu (PT. Nusa Konstruksi Enjiniring). Agar pelaksanaan proyek dapat selesai sesuai dengan jadwal rencana perlu dilakukan percepatan. Namun mempercepat proyek tersebut membutuhkan tambahan biaya.

Keterlambatan proyek dapat diatasi dengan mengadakan percepatan durasi proyek namun percepatan durasi dapat mengakibatkan pertambahan biaya. Metoda yang dapat digunakan adalah time cost trade off atau pertukaran waktu dan biaya. Metoda ini dapat dilakukan dengan mengubah metode konstruksi, menambah jumlah pekerja serta peralatan, mengadakan shift pekerjaan, menggunakan material yang lebih cepat penggunaannya, dan dengan menambah jam kerja atau lembur. Pada penelitian ini akan di aplikasikan metoda time cost trade off untuk mengejar keterlambatan. Keterlambatan diantaranya disebabkan karena, keterlambatan di GWT (Ground Water Tank), STP (Sewage Treatment Plan) dikarenakan keluarnya air secara terus-menerus dari bawah tanah sehingga menggenangi area tersebut, rusaknya Tower Crane, sehingga kontraktor perlu melakukan percepatan untuk menghindari keterlambatan proyek secara keseluruhan. Apabila penyelesaian proyek terlambat, maka kontraktor akan terkena sangsi berupa denda yang telah disepakati dalam dokumen kontrak.

\section{METODE PENELITIAN}

\section{Lokasi Studi}

Lokasi proyek pembangunan Hotel Aston Paramount terletak pada Jalan S. Parman No. 87 89 Malang Jawa Timur.

\section{Pengumpulan Data}

Adapun data-data yang diperlukan dalam penelitian ini antara lain :

- Gambar perencanaan proyek.
- Jadwal pelaksanaan (time schedule) proyek yang berupa kurva $\mathrm{S}$ untuk menentukan durasi normal sesuai dengan pelaksanaan proyek.

- Rincian Anggaran Biaya (RAB) untuk menentukan biaya normal yang dibuat sebagai acuan menghitung biaya percepatan.

- Alokasi sumber daya/tenaga kerja tiap-tiap aktivitas dan analisa harga satuan proyek pembangunan Hotel Aston Paramount MalangJawa Timur.

- Observasi, yaitu pengamatan langsung yang dilakukan penulis pada saat melakukan kerja praktek di proyek yang bersangkutan.

\section{Proses Penelitian}

- Analisa Normal Duration dan Normal Cost adalah menganalisa data Normal Duration dan Cost diperoleh dari pengumpulan data.

- Menyusun Arrow Diagram pada tiap-tipa aktivitas pekerjaan adalah memecah tiap-tiap aktifitas (breakdown) dari aktifitas keseluruhan proyek.

- Menganalisa Crash Duration, Crash Cost, dan Cost Slope adalah mencari Crash Duration, dengan mengasumsikan penambahan jam kerja, jumlah pekerja, peralatan. Selanjutnya, didapat durasi percepatan dan biaya biaya percepatan. Dan Cost slope dihitung dengan rumus sebagai berikut :

$$
\text { Cost slope }=\text { Crash cost }- \text { Normal Cost }
$$

Normal duration - Cost duration

- Melakukan analisa TCTO mengkompresi pada lintasan kritis yang mempunyai nilai cost slope terendah. Menyusun kembali jaringan kerja kemudian melakukan kompresi lagi pada lintasan kritis yang mempunyai nilai cost slope terendah. Kompresi terus dilakukan sampai salah satu lintasan kritis mempunyai aktivitasaktivitas yang telah jenuh seluruhnya (tidak mungkin dikompresi lagi) sehingga pengendalian biaya telah optimum.

- Menghitung berapa biaya tambahan dan waktu percepatan optimum proyek. 


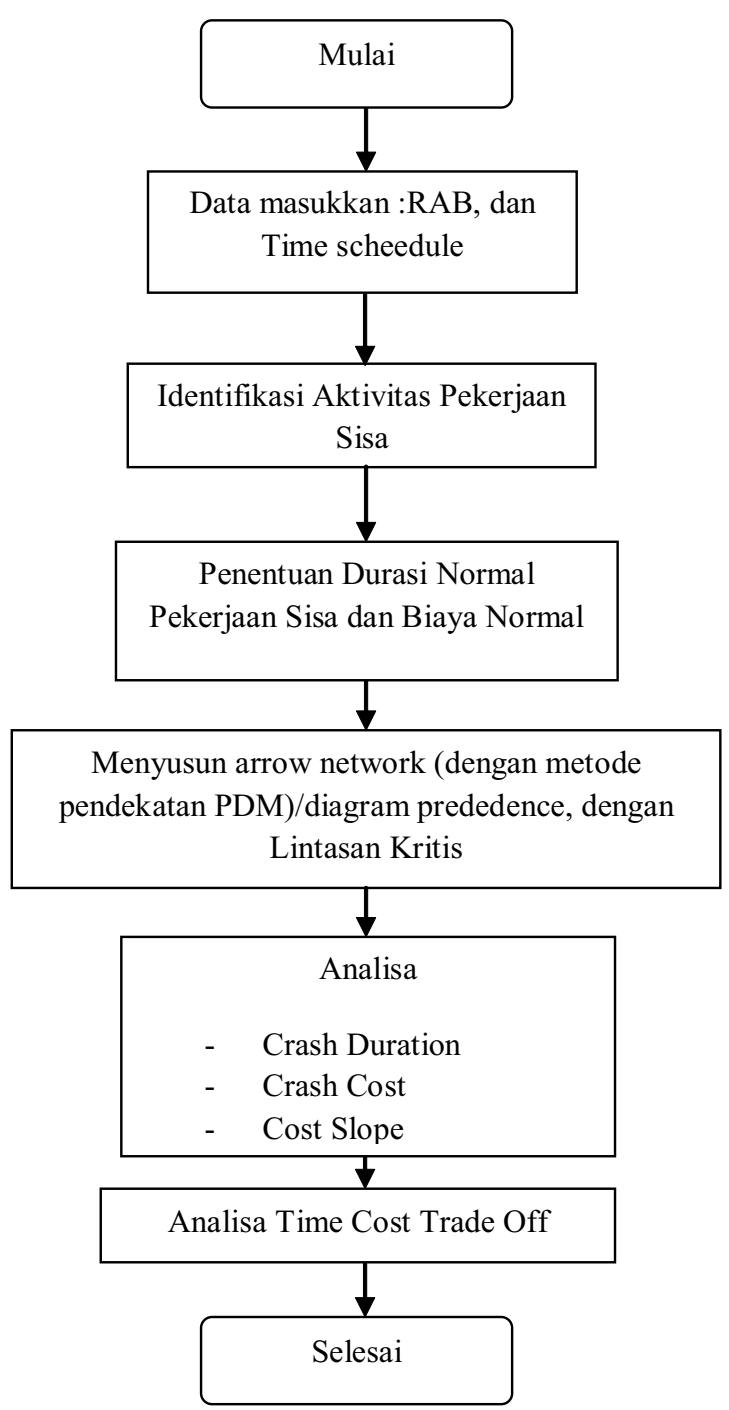

Gambar 1. Diagram Alir tahapan Studi

HASIL DAN PEMBAHASAN

\section{Analisa Harga Satuan Pekerjaan}

Harga satuan adalah perkalian antara koefisien pekerjaan dengan harga upah / bahan. Harga satuan pekerjaan merupakan faktor yang berpengaruh besar terhadap biaya proyek. Contoh perhitungan harga satuan pada $1 \mathrm{~m}^{3}$ pekerjaan pasangan pondasi batu belah dapat dilihat pada tabel 1 .

Tabel 1. Analisa Harga Satuan Pekerjaan

\begin{tabular}{|c|c|c|c|c|c|c|}
\hline $\begin{array}{c}\text { Uraian } \\
\text { Pekerjaan }\end{array}$ & Koef & Sat & $\begin{array}{c}\text { Harga } \\
\text { Satuan } \\
\text { (rp) }\end{array}$ & $\begin{array}{c}\text { Jumlah Harga } \\
\text { Bahan(rp) }\end{array}$ & $\begin{array}{c}\text { Jumlah } \\
\text { Harga } \\
\text { Upah(rp) }\end{array}$ & Jumlah (rp) \\
\hline \multicolumn{7}{|c|}{ Pas. Pondasi Batu Belah 1 PC:6 Ps } \\
\hline Batu belah & 1,100 & $\mathrm{~m}^{3}$ & $139.900,00$ & $153.890,00$ & & \\
\hline Semen PC & $\begin{array}{c}117,00 \\
0\end{array}$ & $\mathrm{Kg}$ & $1.350,00$ & $157.950,00$ & & \\
\hline Pasir pasang & 0,561 & $\mathrm{~m}^{3}$ & $132.000,00$ & $74.052,00$ & & \\
\hline Pekerja & 1,500 & $\mathrm{Oh}$ & $39.000,00$ & & $58.500,00$ & \\
\hline Tukang batu & 0,600 & $\mathrm{Oh}$ & $47.250,00$ & & $28.350,00$ & \\
\hline Kepala Tukang & 0,060 & $\mathrm{Oh}$ & $50.250,00$ & & $3.015,00$ & \\
\hline \multirow[t]{2}{*}{ Mandor } & 0,075 & $\mathrm{Oh}$ & $59.250,00$ & & $4.443,75$ & \\
\hline & & & & $385.892,00$ & $94.308,75$ & $480.200,75$ \\
\hline
\end{tabular}




\section{Analisa Rencana Anggaran Biaya}

Analisa Anggaran Biaya (RAB) adalah rencana pengeluaran biaya proyek yang dianalisa dari perincian macam pekerjaan, volume pekerjaan yang dikalikan harga satuan didapat Rencana Anggaran Biaya total.

Tabel 2. Rencana Anggaran Biaya

\begin{tabular}{|c|c|c|c|c|c|c|}
\hline NO & $\begin{array}{c}\text { URAIAN } \\
\text { PEKERJAAN }\end{array}$ & VOL & SAT & $\begin{array}{c}\text { HARGA } \\
\text { SATUAN } \\
(\mathrm{Rp})\end{array}$ & $\begin{array}{c}\text { JUMLAH } \\
\text { HARGA (Rp) }\end{array}$ & $\begin{array}{l}\text { TOTAL } \\
\text { (Rp) }\end{array}$ \\
\hline A & PEKERJAAN TANAH & & & & & \\
\hline 1 & Galian tanah alat & 389,96 & $\mathrm{~m}^{3}$ & $17.850,00$ & $6.960 .786,00$ & \\
\hline 2 & Galian tanah manual & 189,25 & $\mathrm{~m}^{3}$ & $30.731,35$ & $5.815 .907,99$ & \\
\hline 3 & Buang tanah & 532,07 & $\mathrm{~m}^{3}$ & $26.250,00$ & $13.966 .837,50$ & \\
\hline 4 & Pasir urug $\mathrm{t}=100 \mathrm{~mm}$ & 38,21 & $\mathrm{~m}^{3}$ & $109.972,50$ & $4.202 .049,23$ & \\
\hline 5 & Pas. Batu kosong & 15,87 & $\mathrm{~m}^{3}$ & $247.638,00$ & $3.930 .015,06$ & \\
\hline 6 & Pas. Batu kali & 46,55 & $\mathrm{~m}^{3}$ & $480.200,75$ & $22.353 .344,91$ & \\
\hline 7 & Pot. Bore pile $\mathrm{d}=600$ & 55,00 & Titik & $65.000,00$ & $3.75 .000,00$ & \\
\hline 8 & Pot. Bore pile $\mathrm{d}=800$ & 18,00 & Titik & $75.000,00$ & $6.000 .000,00$ & \\
\hline 9 & Anti rayap & 634,00 & $\mathrm{~m}^{2}$ & $21.530,00$ & $13.650 .020,00$ & \\
\hline \multirow[t]{3}{*}{10} & Perkuatan jembatan & 1,00 & Ls & $15.000 .000,00$ & $15.000 .000,00$ & \\
\hline & & & & JUMLAH & $90.803 .960,69$ & \\
\hline & Total Biaya Pembangu & Ian Hote & ston I & mount Malang & 32.679 & $10.571,24$ \\
\hline
\end{tabular}

Analisa Sumber Daya

Analisa sumber daya (tenaga kerja) membahas masalah berapa tenaga kerja dan bahan yang diperlukan untuk mengerjakan / menyelesaikan suatu jenis pekerjaan. Beberapa faktor yang juga mempengaruhi dalam mempertimbangkan jumlah hari yang dibutuhkan untuk menyelesaikan suatu jumlah pekerjaan diantaranya:
- Volume pekerjaan dan luas lokasi

- Cuaca

- $\quad$ Keadaan geografi dan topografi

Berikut contoh perhitungan kebutuhan sumber daya berdasarkan produktivitas pekerja dan bahan dapat lihat pada tabel 3 dan durasi waktu pada tabel 4.

Tabel 3. Analisa Kebutuhan Sumber Daya dan Material

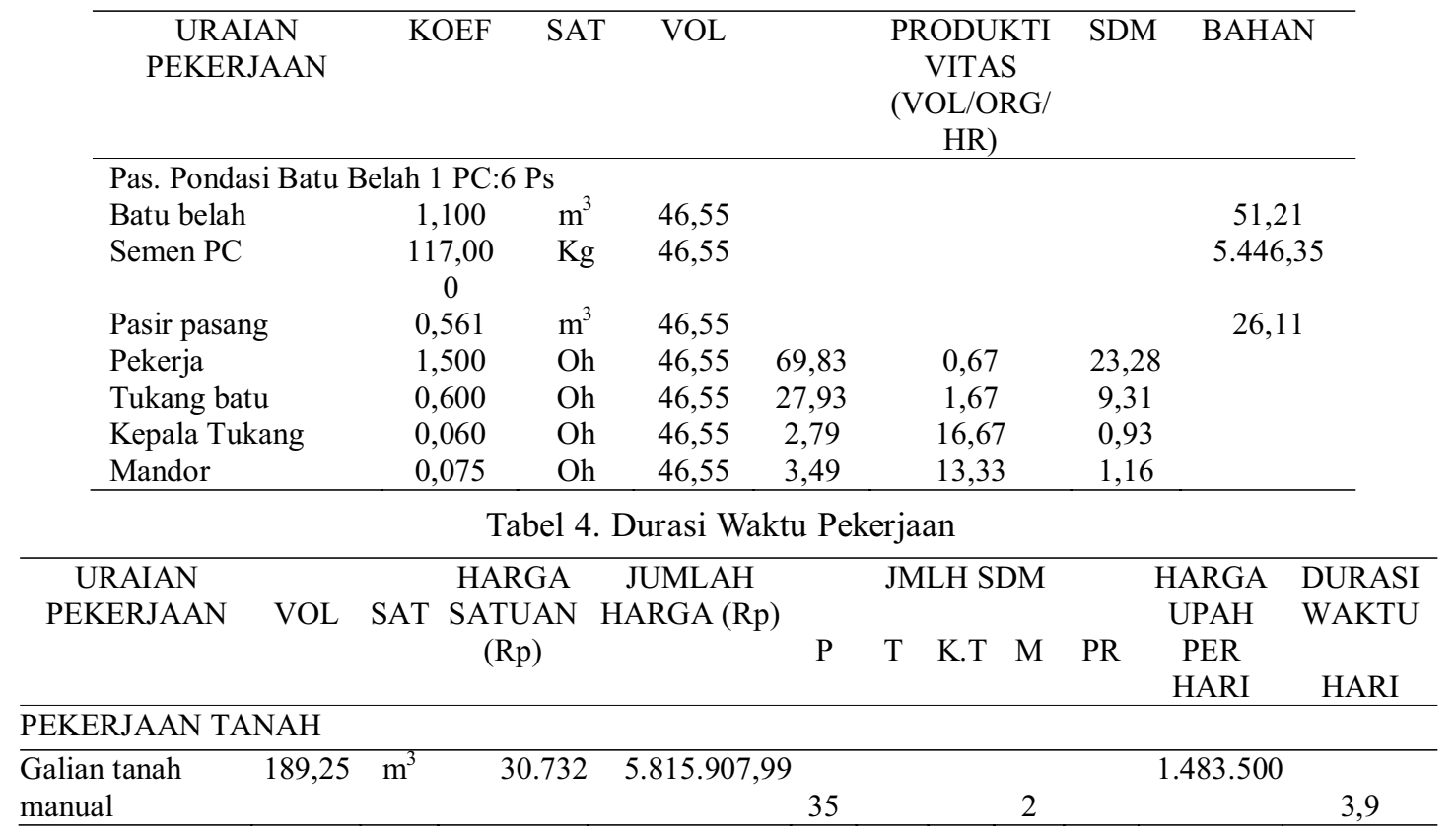




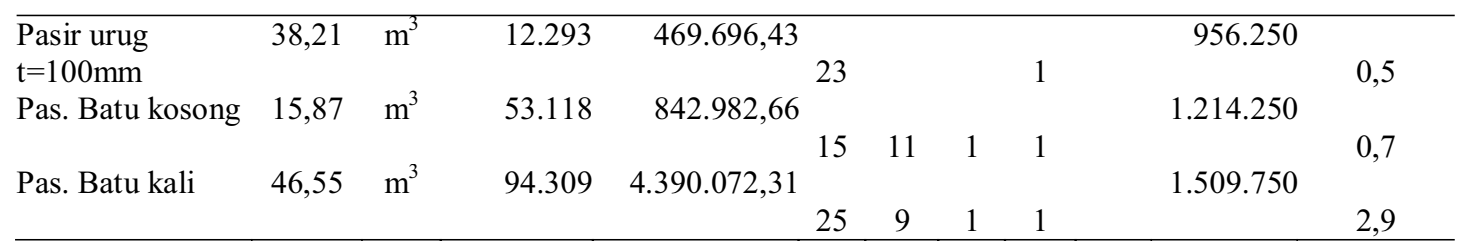

Hubungan Ketergantungan

Tabel 5. Hubungan ketergantungan

\begin{tabular}{cccccccc}
\hline \multirow{2}{*}{ KEGIATAN } & HUB- & $\begin{array}{c}\text { PALING } \\
\text { DURASI }\end{array}$ & $\begin{array}{c}\text { PALING } \\
\text { AKHIR }\end{array}$ & FLOAT \\
& KETERGANTUNGAN & (HARI) & ES & EF & LS & LF & (HARI) \\
\hline A & & 162 & 0 & 162 & 0 & A & \\
B & A SS & 6 & 0 & 6 & 0 & B & A SS \\
C & B SS & 18 & 0 & 18 & 0 & C & B SS \\
D & C SS & 24 & 0 & 24 & 0 & D & C SS \\
E & D SS & 24 & 0 & 24 & 0 & E & D SS \\
F & E SS 6 & 54 & 6 & 54 & 6 & F & E SS 6 \\
G & F SS & 24 & 6 & 30 & 6 & G & F SS \\
H & G SS & 12 & 6 & 18 & 6 & H & G SS \\
I & H SS 6 & 18 & 12 & 30 & 12 & I & H SS 6 \\
J & I SS & 24 & 12 & 36 & 12 & J & I SS \\
K & J SS 12 & 24 & 24 & 42 & 24 & K & J SS 12 \\
L & K SS 6 & 18 & 30 & 48 & 30 & L & K SS 6 \\
M & L SS 6 & 18 & 36 & 54 & 36 & M & L SS 6 \\
N & M SS 6 & 18 & 42 & 60 & 42 & N & M SS 6 \\
O & Q FS -42 & 72 & 78 & 150 & 90 & O & Q FS -42 \\
P & H FS 18, I FS 12 & 60 & 36 & 96 & 60 & P & I FS 12 \\
& & & & & & & E FS - \\
Q & E FS -24, N FS -60 & 120 & 0 & 120 & 0 & Q & -60 FS \\
R & S SS -12 & 108 & 18 & 126 & 24 & R & S SS -12 \\
S & Q SS 30 & 84 & 30 & 114 & 30 & S & Q SS 30 \\
T & S SS 12 & 102 & 42 & 144 & 42 & T & S SS 12 \\
U & R SS 30 & 90 & 48 & 138 & 54 & U & R SS 30 \\
W & T SS -36 & 78 & 6 & 84 & 6 & W & T SS -36 \\
X & W FS 6 & 72 & 78 & 150 & 84 & X & W FS 6 \\
Y & W FS -6, Z SS -6 & 78 & 78 & 156 & 78 & Y & W FS -6 -6 \\
Z & O SS -6 & 90 & 72 & 162 & 72 & Z & O SS -6 \\
\hline & & & & & & &
\end{tabular}

\section{Identifikasi Aktivitas dari Sisa Pekerjaan}

Berdasarkan laporan pekerjaan minggu ke 17 pada tanggal 5 November 2012 sampai 11 Oktober 2012, terlihat bahwa proyek mengalami keterlambatan. Pada minggu ke 17 proyek seharusnya sudah diselesaikan $25,673 \%$, namun pada kenyataannya proyek baru diselesaikan $24,194 \%$, hal ini berarti bahwa proyek mengalami keterlambatan $-1,478 \%$. Untuk itu, dari semua aktivitas sisa tersebut perlu dilakukan analisa agar proyek tidak mengalami keterlambatan.

\section{Penyusunan Network Diagram}

Setelah didapatkan hubungan antar aktivitas dan durasi masing - masing akivitas, maka langkah selanjutnya yaitu membuat jaringan kerja (network 
planning). Dari hasil network planning, dapat diketahui durasi sisa pekerjaan yaitu 150 hari dengan lintasan kritis pada pekerjaan A-B-C-D-E-F-G-HI-J-K-L-M-N-Q-R-S-T-W-Y-Z.

\section{Cost slope}

Dengan adanya percepatan durasi pelaksanaan pada aktivitas tertentu, maka akan terjadi pertambahan biaya akibat percepatan durasi tersebut. Pertambahan biaya percepatan tersebut tergantung besarnya durasi percepatan yang direncanakan serta total biaya setelah percepatan (crash cost). Semakin besar crash costnya, maka akan semakin besar nilai cost slope nya.

$$
\text { Cost Slope }=\frac{\text { Crash Cost }- \text { Normal Cost }}{\text { Normal duration }- \text { Cost duration }}
$$

Adapun asumsi batasan yang saya gunakan sebagai berikut:

- Perubahan biaya yang terjadi akibat percepatan waktu hanya terjadi pada upah sumber daya

- Pemberlakuan waktu jam kerja shift 4 jam, sehingga jam kerja normal 8 jam ditambah waktu shift 4 jam menjadi 12 jam kerja

- Biaya sumber daya manusia untuk waktu lembur diperhitungkan sebesar $1 \mathrm{x}$ dari jam kerja normal

- Biaya peralatan tidak mengalami perubahan

Analisa cost slope akan diuraikan satu persatu sebagai berikut:

- Pekerjaan tanah

- Galian Tanah Manual

$\begin{array}{ll}\text { Volume } & =189,25 \mathrm{~m}^{3} \\ \text { Normal Duration } & =4 \text { hari } \\ \text { Normal Cost } & =\text { Rp. } 1.483 .500\end{array}$

\section{Crash Duration}

$\begin{array}{ll}1 \text { hari }(\text { crash }) & =8+4=12 \text { jam } \\ \text { Total jam aktivitas } & =4 \text { hari } \times 8 \text { jam }=32 \text { jam } \\ \text { Crash duration } & =32 / 12=3 \text { hari }\end{array}$

http://ejournal.umm.ac.id/index.php/jmts/article/view/2039

$$
\frac{189,25 \times R p 30.731,25}{4 \times 8}=R p .181 .746,53 / \mathrm{jam}
$$

Upah lembur / jam $\quad=1 \times R p .181 .746,53$

$=R p .181 .746,53 / \mathrm{jam}$

Crash 3 hari

$=3 \times 4 \times R p .181 .746,53$

$=$ Rp.2.180.958,36

$=$ Rp. $1.483 .500+$

Rp.2.180.958,36

$=$ Rp.3.664.459

Cost slope $=$

$$
\frac{R p 3.664 .459-R p \cdot 1.483 .50 C}{4-3}=R p .2 .180 .959 / \text { hari }
$$

- $\quad$ Pasangan batu kali

Volume $=46,55 \mathrm{~m}^{3}$

Normal Duration $=3$ hari

Normal Cost $=$ Rp. 1.509 .750

\section{Crash Duration}

$$
\begin{array}{ll}
1 \text { hari }(\text { crash }) & =8+4=12 \text { jam } \\
\text { Total jam aktivitas } & =3 \text { hari } \times 8 \text { jam }=24 \text { jam } \\
\text { Crash duration } & =24 / 12=2 \text { hari }
\end{array}
$$

\section{Crash Cost}

Upah normal

$$
\frac{46,55 \times \operatorname{Rg} 94308,75}{3 \times 8}=R p \cdot 182.919,68 / \mathrm{jam}
$$

Upah lembur / jam $\quad=1 \times R p .182 .919,68$

$$
=R p .182 .919,68 / \text { jam }
$$

Crash 2 hari

$$
=2 \times 4 \times R p .182 .919,68
$$

Total crash cost

$$
=\operatorname{Rp} .1 .463 .357,44
$$$$
=\text { Rp.1.509.750+ }
$$$$
\text { Rp.1.463.357,4 }
$$$$
=\text { Rp.2.973.107 }
$$

Cost slope

$$
=
$$

$$
\frac{\text { Ry.2.973.107-Ry.1.509.75C }}{3-2}=R p .1 .463 .358 / \text { hari }
$$

\section{Crash Cost}

Upah normal 
Tabel 6. Kompresi 1

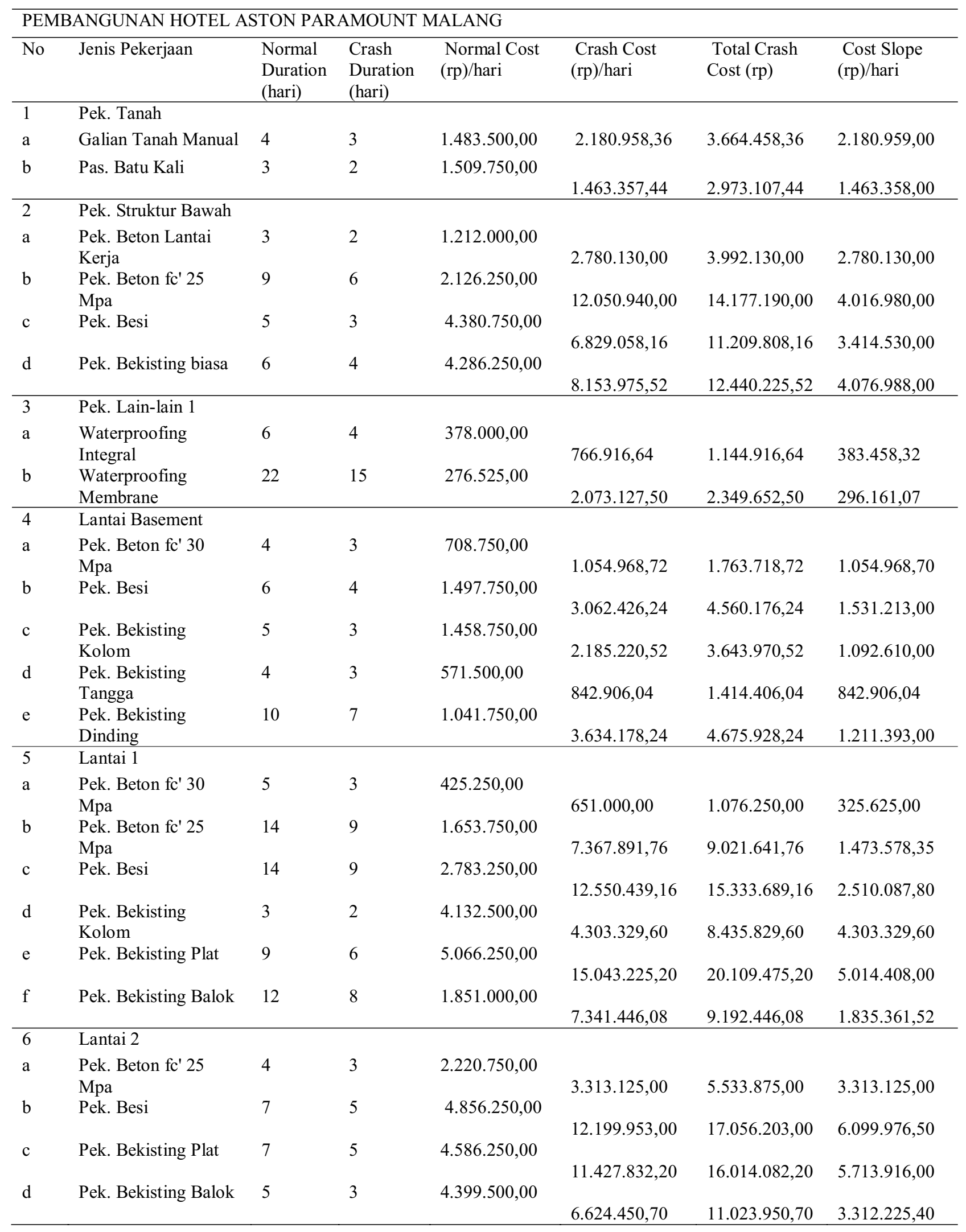




\begin{tabular}{|c|c|c|c|c|c|c|c|}
\hline 7 & Lantai 3 & & & & & & \\
\hline \multirow[t]{2}{*}{$\mathrm{a}$} & Pek. Beton fc' 25 & 3 & 2 & $1.653 .750,00$ & \multirow[b]{2}{*}{$1.654 .676,64$} & \multirow[b]{2}{*}{$3.308 .426,64$} & \multirow[b]{2}{*}{$1.654 .677,00$} \\
\hline & Mpa & & & & & & \\
\hline $\mathrm{b}$ & Pek. Besi & 5 & 3 & $3.837 .750,00$ & & & \\
\hline \multirow{3}{*}{ c } & & & & & $5.728 .156,68$ & $9.565 .906,68$ & $2.864 .078,34$ \\
\hline & Pek. Bekisting & 3 & 2 & $3.270 .000,00$ & & & \\
\hline & Dinding & & & & $3.222 .738,80$ & $6.492 .738,80$ & $3.222 .738,80$ \\
\hline 8 & Lantai 5 & & & & & & \\
\hline \multirow[t]{2}{*}{$\mathrm{a}$} & Pek. Beton fc' 30 & 3 & 2 & $1.464 .750,00$ & & & \\
\hline & Mpa & & & & $1.452 .040,00$ & $2.916 .790,00$ & $1.452 .040,00$ \\
\hline \multirow[t]{2}{*}{$\mathrm{b}$} & Pek. Beton fc' 25 & 5 & 3 & $1.795 .500,00$ & & & \\
\hline & Mpa & & & & $2.710 .020,00$ & $4.505 .520,00$ & $1.355 .010,00$ \\
\hline \multirow[t]{2}{*}{ c } & Pek. Besi & 7 & 5 & $5.125 .500,00$ & & & \\
\hline & & & & & $12.745 .846,60$ & $17.871 .346,60$ & $6.372 .923,00$ \\
\hline \multirow[t]{2}{*}{$\mathrm{d}$} & Pek. Bekisting & 3 & 2 & $2.627 .250,00$ & & & \\
\hline & Kolom & & & & $2.618 .025,04$ & $5.245 .275,04$ & $2.618 .025,04$ \\
\hline \multirow[t]{2}{*}{$\mathrm{e}$} & Pek. Bekisting Plat & 5 & 3 & $4.430 .250,00$ & $6.549 .276,00$ & & \\
\hline & & & & & & $10.979 .526,00$ & $3.274 .638,00$ \\
\hline \multirow[t]{2}{*}{ f } & Pek. Bekisting Balok & 5 & 3 & $3.489 .750,00$ & & & \\
\hline & & & & & $5.328 .156,00$ & $8.817 .906,00$ & $2.664 .078,00$ \\
\hline 9 & Lantai 6 & & & & & & \\
\hline \multirow[t]{2}{*}{$\mathrm{a}$} & Pek. Beton fc' 25 & 6 & 4 & $1.271 .000,00$ & & & \\
\hline & Mpa & & & & $2.544 .893,28$ & $3.815 .893,28$ & $1.272 .446,64$ \\
\hline \multirow[t]{2}{*}{$\mathrm{b}$} & Pek. Besi & 5 & 3 & $6.567 .000,00$ & & & \\
\hline & & & & & $9.943 .467,48$ & $16.510 .467,48$ & $4.971 .734,00$ \\
\hline \multirow[t]{2}{*}{$\mathrm{c}$} & Pek. Bekisting & 3 & 2 & $2.493 .750,00$ & & & \\
\hline & Kolom & & & & $2.581 .196,80$ & $5.074 .946,80$ & $2.581 .196,80$ \\
\hline \multirow[t]{2}{*}{$\mathrm{d}$} & Pek. Bekisting Plat & 6 & 4 & 4.399.500,00 & & & \\
\hline & & & & & $8.798 .523,20$ & $13.198 .023,20$ & 4.399.261,60 \\
\hline \multirow[t]{2}{*}{ e } & Pek. Bekisting Balok & 6 & 4 & $3.873 .750,00$ & & & \\
\hline & & & & & $7.738 .785,28$ & $11.612 .535,28$ & $3.869 .392,60$ \\
\hline 10 & Lantai 7 & & & & & & \\
\hline $\mathrm{a}$ & Pek. Beton fc' 25 & 4 & 3 & $1.891 .000,00$ & & & \\
\hline & Mpa & & & & $2.866 .027,56$ & $4.757 .027,56$ & $2.866 .027,56$ \\
\hline $\mathrm{b}$ & Pek. Besi & 6 & 4 & $5.265 .000,00$ & & & \\
\hline & & & & & $10.604 .235,68$ & $15.869 .235,68$ & $5.302 .117,80$ \\
\hline $\mathrm{c}$ & Pek. Bekisting Plat & 5 & 3 & $5.253 .750,00$ & & & \\
\hline & & & & & 7.918.670,88 & $13.172 .420,88$ & $3.959 .335,40$ \\
\hline d & Pek. Bekisting Balok & 4 & 3 & $5.810 .250,00$ & & & \\
\hline & & & & & $8.796 .730,56$ & $14.606 .980,56$ & $8.796 .730,56$ \\
\hline 11 & Lantai 8 & & & & & & \\
\hline $\mathrm{a}$ & Pek. Beton fc' 25 & 4 & 3 & $1.891 .000,00$ & & & \\
\hline & Mpa & & & & $2.866 .027,56$ & $4.757 .027,56$ & $2.866 .027,56$ \\
\hline $\mathrm{b}$ & Pek. Besi & 6 & 4 & $5.265 .000,00$ & & & \\
\hline & & & & & $10.604 .235,68$ & $15.869 .235,68$ & $5.302 .117,80$ \\
\hline $\mathrm{c}$ & Pek. Bekisting Plat & 5 & 3 & $5.253 .750,00$ & & & \\
\hline & & & & & 7.918.670,88 & $13.172 .420,88$ & $3.959 .335,40$ \\
\hline d & Pek. Bekisting Balok & 4 & 3 & $5.810 .250,00$ & & & \\
\hline & & & & & $8.796 .730,56$ & $14.606 .980,56$ & $8.796 .730,56$ \\
\hline 12 & Lantai 9 & & & & & & \\
\hline $\mathrm{a}$ & Pek. Beton fc' 25 & 4 & 3 & $1.891 .000,00$ & & & \\
\hline & Mpa & & & & $2.866 .027,56$ & $4.757 .027,56$ & $2.866 .027,56$ \\
\hline b & Pek. Besi & 6 & 4 & $5.265 .000,00$ & & & \\
\hline & & & & & $10.531 .872,00$ & $15.796 .872,00$ & $5.265 .936,00$ \\
\hline $\mathrm{c}$ & Pek. Bekisting Plat & 5 & 3 & $5.253 .750,00$ & & & \\
\hline & & & & & $7.918 .670,88$ & $13.172 .420,88$ & $3.959 .336,00$ \\
\hline d & Pek. Bekisting Balok & 4 & 3 & $5.763 .000,00$ & & & \\
\hline & & & & & $8.733 .436,68$ & $14.496 .436,68$ & $8.733 .437,00$ \\
\hline
\end{tabular}




\begin{tabular}{|c|c|c|c|c|c|c|c|}
\hline 13 & Lantai Atap & & & & & & \\
\hline \multirow[t]{2}{*}{$\mathrm{a}$} & Pek. Beton fc' 25 & 7 & 5 & $1.240 .000,00$ & \multirow{3}{*}{$3.116 .275,00$} & \multirow{3}{*}{$4.356 .275,00$} & \multirow{3}{*}{$1.000 .137,50$} \\
\hline & Mpa & & & & & & \\
\hline \multirow[t]{2}{*}{$\mathrm{b}$} & Pek. Besi & 5 & 3 & $5.515 .500,00$ & & & \\
\hline & & & & & $8.293 .497,00$ & $13.808 .997,00$ & $4.146 .748,50$ \\
\hline \multirow[t]{2}{*}{$\mathrm{c}$} & Pek. Bekisting Plat & 9 & 6 & $3.473 .250,00$ & & & \\
\hline & & & & & $10.439 .026,08$ & 13.912.276,08 & $3.479 .675,40$ \\
\hline d & Pek. Bekisting Balok & 7 & 5 & $3.826 .500,00$ & $9.610 .407,80$ & $13.436 .907,80$ & \\
\hline 14 & Pek. Lain-lain 2 & & & & & & \\
\hline $\mathrm{a}$ & $\begin{array}{l}\text { Waterproofing } \\
\text { Membrane }\end{array}$ & 114 & 76 & $243.000,00$ & $8.804 .557,44$ & $9.047 .557,44$ & $231.698,88$ \\
\hline 15 & Pek. Plafond & & & & & & \\
\hline \multirow[t]{2}{*}{$\mathrm{a}$} & Skimcoat & 22 & 15 & $2.025 .447,00$ & & & \\
\hline & & & & & $15.190 .849,20$ & $17.216 .296,20$ & $2.170 .121,30$ \\
\hline \multirow[t]{2}{*}{$\mathrm{b}$} & Plafond GRC $\mathrm{t}=6 \mathrm{~mm}$ & 19 & 13 & $701.146,00$ & & & \\
\hline & & & & & $4.557 .447,44$ & $5.258 .593,44$ & $759.574,57$ \\
\hline \multirow[t]{2}{*}{$\mathrm{c}$} & Drop Ceilling & 38 & 25 & $887.852,00$ & & & \\
\hline & & & & & $11.098 .100,00$ & $11.985 .952,00$ & $853.700,00$ \\
\hline 16 & Pek. Lain-lain & & & & & & \\
\hline \multirow[t]{2}{*}{$\mathrm{a}$} & Pek. Railling Tangga & 35 & 23 & $435.300,00$ & & & \\
\hline & & & & & $5.051 .950,00$ & $5.487 .250,00$ & $420.995,83$ \\
\hline 17 & Pek. Luar & & & & & & \\
\hline \multirow[t]{2}{*}{$\mathrm{a}$} & Pek. Gutter & 5 & 3 & $570.000,00$ & & & \\
\hline & $\mathrm{h}=300 \mathrm{~mm}$ & & & & $849.690,00$ & $1.419 .690,00$ & $424.845,00$ \\
\hline \multirow[t]{2}{*}{$\mathrm{b}$} & Kanstain Beton & 15 & 10 & $306.000,00$ & & & \\
\hline & & & & & $1.531 .926,80$ & $1.837 .926,80$ & $306.385,36$ \\
\hline \multirow[t]{2}{*}{$\mathrm{c}$} & Pek. Asphalt & 31 & 21 & $2.625 .000,00$ & & & \\
\hline & & & & & $27.515 .080,32$ & $30.140 .080,32$ & $2.751 .508,00$ \\
\hline \multirow[t]{2}{*}{ d } & Pas. Dinding Bata & 7 & 5 & $1.259 .250,00$ & & & \\
\hline & Ringan & & & & $3.188 .154,40$ & $4.447 .404,40$ & $1.594 .077,20$ \\
\hline \multirow[t]{2}{*}{$\mathrm{e}$} & Pek. Plester + Acian & 7 & 5 & $1.776 .750,00$ & & & \\
\hline & & & & & $4.163 .740,00$ & $5.940 .490,00$ & $2.081 .870,00$ \\
\hline f & Lantai Keramik & 3 & 2 & $1.729 .500,00$ & & & \\
\hline & $165 \times 666 \mathrm{~mm}$ & & & & $1.733 .271,84$ & $3.462 .771,84$ & $1.733 .271,84$ \\
\hline $\mathrm{g}$ & Allumunium & 9 & 5 & $650.750,00$ & & & \\
\hline & Composite & & & & $1.568 .460,00$ & $2.219 .210,00$ & $392.115,00$ \\
\hline $\mathrm{h}$ & Atap Sky Light & 3 & 2 & $675.000,00$ & & & \\
\hline & & & & & $705.000,00$ & $1.380 .000,00$ & $705.000,00$ \\
\hline $\mathrm{i}$ & Galian Tanah Manual & 5 & 3 & $566.250,00$ & & & \\
\hline & & & & & $829.467,12$ & $1.395 .717,12$ & $414.733,56$ \\
\hline $\mathrm{j}$ & Pas. Batu Kali & 5 & 3 & $1.017 .000,00$ & & & \\
\hline & & & & & $1.409 .538,60$ & $2.426 .538,60$ & $704.769,30$ \\
\hline 18 & $\begin{array}{l}\text { Pek. Atap, } \\
\text { Fasade\&Kulit Luar }\end{array}$ & & & & & & \\
\hline $\mathrm{a}$ & Pek. Curtain Wall & 10 & 7 & $2.352 .000,00$ & & & \\
\hline & Kaca $8 \mathrm{~mm}$ & & & & $8.171 .170,00$ & $10.523 .170,00$ & $2.723 .723,30$ \\
\hline $\mathrm{b}$ & Pek. Curtain Wall & 11 & 7 & $2.438 .250,00$ & & & \\
\hline & Kaca $10 \mathrm{~mm}$ & & & & $8.268 .272,60$ & $10.706 .522,60$ & $2.067 .068,20$ \\
\hline $\mathrm{c}$ & Pek. Curtain Wall & 5 & 3 & $3.214 .500,00$ & & & \\
\hline & Kaca 6mm & & & & $4.338 .960,00$ & $7.553 .460,00$ & $2.169 .480,00$ \\
\hline d & Cladding & 19 & 13 & $1.737 .750,00$ & & & \\
\hline & Allumunium & & & & $11.424 .998,52$ & $13.162 .748,52$ & $1.904 .167,00$ \\
\hline e & Panel GRC Precast & 15 & 10 & $3.060 .000,00$ & & & \\
\hline & & & & & $15.063 .600,00$ & $18.123 .600,00$ & $3.012 .720,00$ \\
\hline $\mathrm{f}$ & Cat Emulsion & 9 & 6 & $1.413 .750,00$ & & & \\
\hline & Eksternal & & & & $4.267 .871,76$ & $5.681 .621,76$ & $1.422 .624,00$ \\
\hline g & Jendela $2250 \times 2250$ & 8 & 5 & $2.200 .000,00$ & & & \\
\hline & $\mathrm{mm}$ & & & & $5.187 .500,00$ & $7.387 .500,00$ & $1.729 .166,67$ \\
\hline
\end{tabular}




\begin{tabular}{|c|c|c|c|c|c|c|c|}
\hline $\mathrm{h}$ & $\begin{array}{l}\text { Natt Allumunium Uk. } \\
50\end{array}$ & 9 & 6 & $1.793 .250,00$ & $5.422 .500,00$ & $7.215 .750,00$ & $1.807 .500,00$ \\
\hline $\mathrm{i}$ & $\begin{array}{l}\text { Natt Allumunium Uk. } \\
20\end{array}$ & 5 & 3 & $140.000,00$ & $217.500,00$ & $357.500,00$ & $108.750,00$ \\
\hline $\mathrm{j}$ & Atap Metal Roof & 8 & 5 & $1.487 .250,00$ & $3.747 .415,40$ & $5.234 .665,40$ & $1.249 .138,50$ \\
\hline & JUMLAH & & & & $477.704 .221,68$ & & \\
\hline
\end{tabular}

Tabel 7. Kompresi 2

\begin{tabular}{|c|c|c|c|c|c|c|c|}
\hline \multicolumn{8}{|c|}{ PEMBANGUNAN HOTEL ASTON PARAMOUNT MALANG } \\
\hline No & Jenis pekerjaan & $\begin{array}{c}\text { Normal } \\
\text { duration } \\
\text { (hari) }\end{array}$ & $\begin{array}{l}\text { Crash } \\
\text { duratio } \\
\mathrm{n} \text { (hari) }\end{array}$ & $\begin{array}{l}\text { normal cost } \\
\text { (rp)/hari }\end{array}$ & $\begin{array}{l}\text { crash cost } \\
\text { (rp)/hari }\end{array}$ & $\begin{array}{l}\text { total crash } \\
\text { cost (rp) }\end{array}$ & $\begin{array}{l}\text { cost slope } \\
(\mathrm{rp}) / \text { hari }\end{array}$ \\
\hline 1 & $\begin{array}{l}\text { Pas. Dinding \& } \\
\text { Pelapis }\end{array}$ & & & & & & \\
\hline a & $\begin{array}{l}\text { Pas. Bata Ringan } \\
\mathrm{t}=100 \mathrm{~mm} \\
\text { Pek. Plester }+\end{array}$ & 31 & 21 & $8.518 .294,00$ & $89.442 .086,16$ & $97.960 .380,16$ & 8.944.208,60 \\
\hline $\mathrm{b}$ & $\begin{array}{l}\text { Acian } \\
\text { Pelapis Dinding } \\
\text { Keramik }\end{array}$ & 23 & 15 & $7.898 .012,00$ & $59.235 .087,60$ & $67.133 .099,60$ & $7.404 .386,00$ \\
\hline $\mathrm{c}$ & $30 \times 60 \mathrm{~cm}$ & 26 & 17 & $7.409 .098,00$ & $62.977 .328,24$ & $70.386 .426,24$ & $6.997 .480,90$ \\
\hline 2 & $\begin{array}{l}\text { Pek. Lantai \& } \\
\text { Pelapis } \\
\text { Pas. Homogenous }\end{array}$ & & & & & & \\
\hline $\mathrm{a}$ & $\begin{array}{l}\text { Tile } \\
\text { Waterproofing }\end{array}$ & 28 & 19 & $3.800 .325,00$ & 36.103.087,88 & $39.903 .412,88$ & $4.011 .454,00$ \\
\hline $\mathrm{b}$ & Coating & 19 & 13 & $8.795 .982,00$ & $57.173 .878,32$ & $65.969 .860,32$ & $9.528 .979,70$ \\
\hline & JUMLAH & & & & $304.931 .468,20$ & & \\
\hline & $\begin{array}{l}\text { JUMLAH } \\
\text { TOTAL }\end{array}$ & & & & $782.635 .689,88$ & & \\
\hline
\end{tabular}

\section{KESIMPULAN DAN SARAN}

Kesimpulan

- $\quad$ Berdasarkan jadwal rencana proyek yang mengalami keterlambatan 18 hari proyek selesai dalam waktu sisa 180 hari dengan total biaya Rp. 32.679.810.571,24. Sedangkan apabila proyek dipercepat dengan menggunakan metode TCTO agar kembali ke jadwal rencana awal yaitu 162 hari didapatkan biaya sebesar Rp. 33.462.446.260, selisih antara kedua biaya tersebut Rp. 782.635.689,88.

- Mengoptimalkan alokasi sumber daya manusia akibat adanya percepatan waktu dengan cara mengadakan shift pekerjaan.

\section{Saran}

Untuk menyusun percepatan proyek maka harus diperhitungkan luas lahan dan metode kerja bagi keuntungan penumpukan bahan bangunan, alat dan tenaga kerja.

\section{DAFTAR PUSTAKA}

Meinita Devayanti, Prisca, 2008. Studi Pertukaran Waktu dan Biaya pada Proyek Pembangunan Gedung Perpustakaan Umum Kabupaten Pamekasan. Disertasi tidak diterbitkan. Malang: Fakultas Teknik Universitas Muhammadiyah.

Nugraha, Paulus. Ishak Natan. dan R, Sutjipto. 1985. Manajemen Proyek Konstruksi 1. Surabaya: Kartika Yudha.

Nugraha, Paulus. Ishak Natan. dan R, Sutjipto. 1986. Manajemen Proyek Konstruksi 2. Surabaya: Kartika Yudha.

Santosa, Budi. 2003, Manajemen Proyek. Surabaya: Guna Widya.

Soeharto, Iman. 1999. Manajemen Proyek Dari Konseptual Sampai Operasional. Jakarta: Erlangga.

Soeharto, Iman. 1995. Manajemen Proyek Dari Konseptual Sampai Operasional Jilid I. Jakarta: Erlangga. 